\title{
腺様衰胞癌の臨床病理学的ならびに免疫組織化学的検討
}

\author{
新谷 悟 - 松村智弘・内藤玲子・上山吉哉
}

\section{A clinicopathological and immunohistochemical study of adenoid cystic carcinoma}

\author{
Satoru Shintani - Tomohiro Matsumura \\ Reiko Naitoh • Yosiya Ueyama
}

\begin{abstract}
Clinical, histological, and immunohistochemical studies were carried out for 19 cases of adenoid cystic carcinoma arising from the major and minor salivary glands. The cases were classified clinically (UICC-TNM system, 1987) and histologically (Szanto et al., 1984). For immunohistochemical detections, monoclonal antibody against $c-m y c$ gene product, $v$-H-ras gene product and EGF-receptor, and poloclonal antibody against c-erb $B_{2}$ gene product were used.

The prognosis of the patients with the tumor of stage $\mathbb{N}$ and/or grade $\mathbb{I}$ were poor. Six out of eight patients of stage $\mathbb{V}$ and 4 out of 5 patients of grade $\mathbb{I l}$ died due to the tumor. $\quad c-m y c$ gene product was detected in 16 out of 19 cases $(84.2 \%)$, without histological grading correlation. In most cases, $c-m y c$ gene product was detected in the nucleus, however, in some cases it was shown in either the nucleus and cytoplasm, Ras $p 21$ protein and c-erb $B_{2}$ gene product were frequently detected in grade I and II cases, so it was suspected that the expression of these proteins were closely related to tumor cell differentiation.
\end{abstract}

Key words: adenoid cystic carcinoma (腺様軎胞癌), clinicopathological study (臨床病理学的 検討), oncogene product (癌邀伝子産物)

緒

\section{言}

腺様整胞癌は，緩慢な発㕕を示寸悪性腫瘍であり，そ の経過は一般に長いが，しばしば䛑められる局所再発や 遠隔転移が臨床上，とくに予後に関して大きな問題とな る。本腫瘍の組織像は多彩であるか゚，組織像の逴いと予 後については，充车性の胞巣が傁位なほと予後が不良て あるとの報告がなされ䏓，癌細胞の分化や增殖の程度

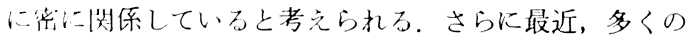

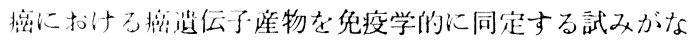

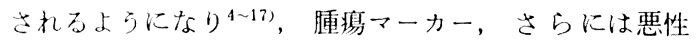
度，転移性などの争後因子としても期待されてきてい る。そこで今同われわれは，腺様整胞癌19例について臨

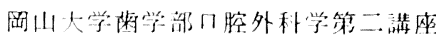

(主任: 松村智弘数授)

The 2nd Department of Oral and Maxillofacial Surgery, School of Dentistry, Okayama University (Chief: Prof. Tomohiro Matsumura) 受付日. 平成 3 年 8 月 19 H
床および病理組織学的所見を㭘討するとともに，癌遗伝 子産物の発現を免疫組織化学的に㭘討したので報告す る.

\section{対象および方法}

刘象症例は1982年 4 月から1990年12月までの 8 年 8 か 月に岡山大学歯学部附属病院第二口腔外科を受診した腺 様整胞癌症例19例である。臨床所見としてこれら症例の 初診時の性別, 年齢, 腫愓の発症部位を，また UICC $(1987)^{19)}$ による唾液腺湾の TNM, stage 分類を用いて 臨床病期について検索した。

また治療法と治療成續についても臨床的雭性度を椧討 する目的で検索した。

またこれら症例の生娭時ならびに手術時に得られた組 織を, 病理組織学的㭘索ならびに免疫組織化学的顿索に 供した。与なわち検索材料を10\%中性緩衝ホルマリンに て固定後, 通法に従いパラフィン包埋, $4 \mu \mathrm{m}$ の切片を作 製し、へマトキシリンーエオジン染色 (H-E 染色)による 組織学的検索を行うとともに，各種の癌遗伝子産物に刘 
する抗体による免度組織化学的染色を施した．組織学的

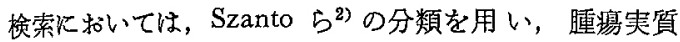
の活としどが管状型和よび節状型で占められるすのを grade I，隀韵実質のほとんどが穊状型であるが充型型 を一部含むるのを grade II，腫㻛実質のほとんどが充実

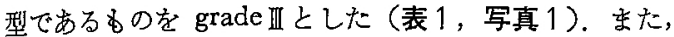
脈管，神経への侵襲について子検索した．免疫組織学的

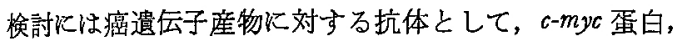
ras $p 21, c$-erbB 2 蛋白, EGF 受容体 (EGF-R) 飞刘す 万抗体学用いた（表 2). 免㾤組織化学的染色は $\mathrm{ABC}$ 法 (adivin-biotin complex method) とより行った。すな わち, 脱パラフィン後, 内因性ペルオキシダーゼ除去の ため，0.3\% $\mathrm{H}_{2} \mathrm{O}_{2}$ 加メタノールを室温30分反応させ，

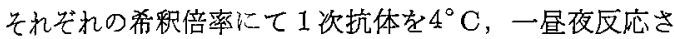

表 1 Histological grading of adenoid cystic carcinoma

Grade I : tumors with tubular and cribriform areas but without solid components.

Grade II : cribriform tumors that were either pure or mixed with less than $30 \%$ of solid areas.

Grade III tumors with a predominantly solid pattern.

(Szanto, P.A., Luna, M.A., et al. 1984)

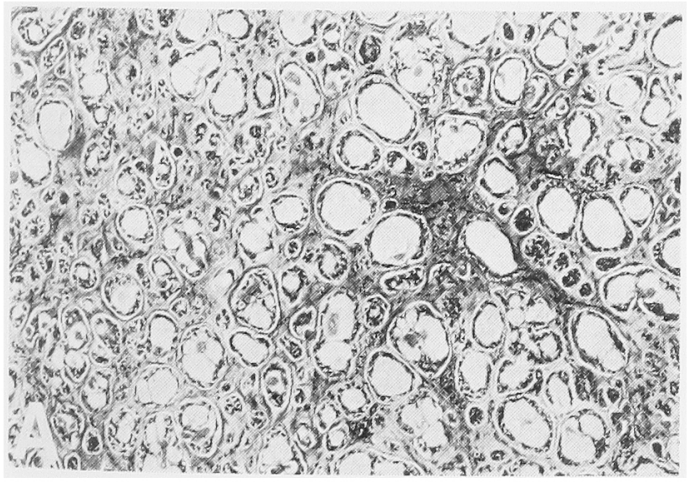

写真 1 A Grade I の病理組織像

(H-E 染色， $\times 100)$
せた，次に 2 次抗体としてビオチン化抗体，さらにアビ ジンービオチン複合物 (Vector Labs.) を室温にて 各 30 分反応させた。発色は 3,3'-diaminobenzidine (DAB) を 用いて行い，メチルグリーンにて対比核染色後，脱水， 透徹，封入乙た。 また 1 次抗体を反応させず，その他の 処理を同様にして免疫組織染色を行い，対照とした。

結果

1. 臨床所見

対象症例19例の性別は，女性11例 (57.9\%)，男性 8

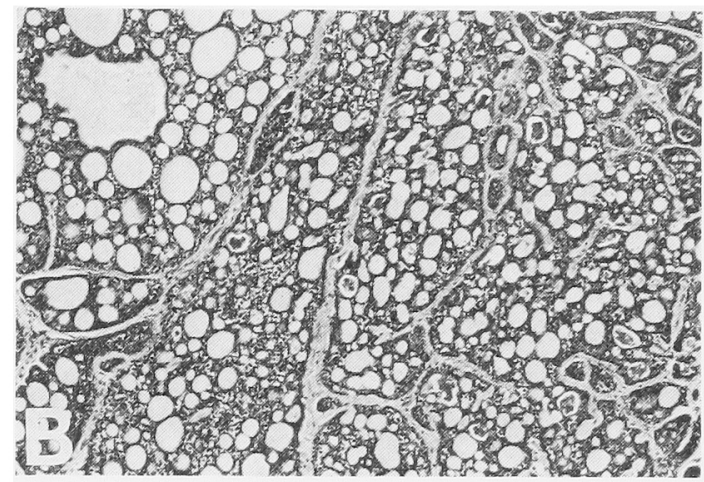

写直 $1 \mathrm{~B}$ Grade II の病理組織像

(H-E 染色, $\times 100)$

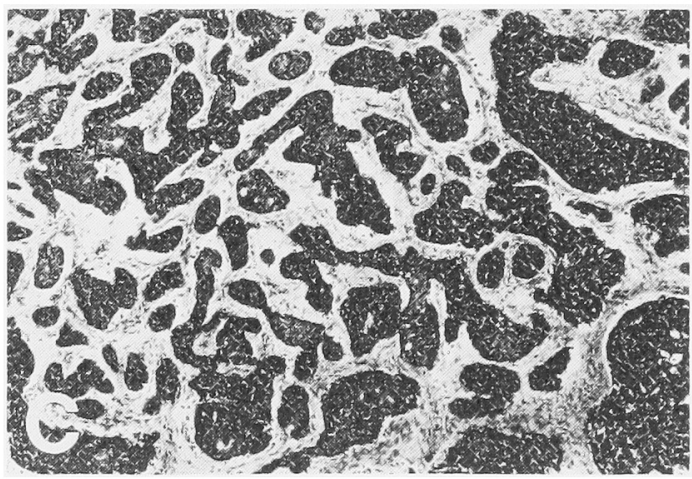

写真 1C Grade III 病理組織像

(H-E 染色， $\times 100)$

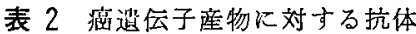

\begin{tabular}{l|c|l}
\hline \multicolumn{1}{c|}{ 抗体 (Clone No.) } & 肴釈倍率 & \multicolumn{1}{|c}{ メーカー } \\
\hline 抗 $c-m y c(9 \mathrm{E} \mathrm{10)}$ & $\times 20$ & Oncogene science Inc. \\
抗 $v-H$ ras (Y 13-259) & $\times 20$ & Oncogene Science Inc. \\
抗 $c-e r b B_{2}$ & $\times 10$ & Triton Bioscience Inc. \\
抗 EGF-R (29.1.1) & $\times 100$ & Sigma \\
\hline
\end{tabular}


表 3 腺様哇胞战19症例の臨休所見

\begin{tabular}{|c|c|c|c|c|c|c|}
\hline No. & 年跲 & 性別 & 原発部位 & TNM (stage) & 治療 & 予 \\
\hline 1 & 41 & 男 & 䝷粘膜 & $\mathrm{T} 4 \mathrm{~b} \mathrm{~N} 0 \mathrm{M} 0$ (IV) & $\mathrm{C}+\mathrm{R}+\mathrm{S}$ & 死 3 年 9 か月 \\
\hline 2 & 63 & 女 & 舌 & $\mathrm{T} 4 \mathrm{~b} \mathrm{~N} 3 \mathrm{MO}$ (IV) & $\mathrm{R}$ & 死 2 年 5 か月 \\
\hline 3 & 66 & 女 & 顎下腺 & $\mathrm{T} 3$ a N $1 \mathrm{M} 0$ ( III) & $\mathrm{R}+\mathrm{S}$ & 生 7 年 1 名月 \\
\hline 4 & 31 & 男 & 顎下腺 & $\mathrm{T} 4 \mathrm{bN} 1 \mathrm{M} 0$ (IV) & $C+R$ & 死 5 年 7 か月 \\
\hline 5 & 55 & 女 & 口底 & $\mathrm{T} 2 \mathrm{bN} 0 \mathrm{M} 0$ (II) & S & 生 5 年 7 か月 \\
\hline 6 & 60 & 女 & 煩粘膜 & $\mathrm{T} 4 \mathrm{bN} 0 \mathrm{M} 0$ (IV) & $\mathrm{S}$ & 生 4 年11か月 \\
\hline 7 & 56 & 女 & 口 蓋 & T 4 b N $0 \mathrm{MO}$ (IV) & $\mathrm{C}+\mathrm{R}+\mathrm{S}$ & 死 2 年 9 か月 \\
\hline 8 & 29 & 女 & 口 蓋 & T 4 b N 0 M 0 (IV) & $\mathrm{C}+\mathrm{R}+\mathrm{S}$ & 生 4 年 8 か月 \\
\hline 9 & 93 & 女 & 口底 & $\mathrm{T} 4 \mathrm{~b} \mathrm{~N} 3 \mathrm{MO}$ (IV) & - & 死 2 年 7 か月 \\
\hline 10 & 48 & 女 & 買下腺 & T 3 a NoM0 (II) & $\mathrm{R}+\mathrm{S}$ & 生 4 年 2 か月 \\
\hline 11 & 84 & 男 & 口底 & T 3 b N 0 M 0 ( III) & S & 生 3 年 10 か月 \\
\hline 12 & 59 & 女 & 顎下腺 & T 2 a $\mathrm{N}_{0} \mathrm{MO}$ ( I ) & $S$ & 生 3 年 7 か月 \\
\hline 13 & 68 & 男 & 口 蓋 & T 4 b N 0 M 1 (IV) & $\mathrm{C}$ & 5 か月 \\
\hline 14 & 52 & 女 & 口 蓋 & $\mathrm{T} 2 \mathrm{bN} 0 \mathrm{M} 0$ (II) & $\mathrm{C}+\mathrm{R}+\mathrm{S}$ & 死 3 年 2 か月 \\
\hline 15 & 57 & 男 & 口 底 & T 3 b NoMo (III) & S & 生 2 年 6 力月 \\
\hline 16 & 78 & 女 & 口 底 & $\mathrm{T} 2$ a $\mathrm{N} 0 \mathrm{MO}$ ( I) & S & 生 2 年 6 か月 \\
\hline 17 & 75 & 男 & 口 蓝 & $\mathrm{T} 2 \mathrm{~b} N 1 \mathrm{M} 0$ (III) & $\mathrm{C}+\mathrm{R}+\mathrm{S}$ & 生 1 年 5 か月 \\
\hline 18 & 65 & 女 & 口 蓋 & T 2 b N $0 \mathrm{MO}$ (II) & $\mathrm{S}$ & 生 1 年 1 か月 \\
\hline 19 & 62 & 男 & 口 蓋 & T 3 b N 0 M 0 (II) & $\mathrm{S}$ & 生 1 年 1 か月 \\
\hline
\end{tabular}

0 ：化学療法， R：放射線療法， S ：外科療法

表 4 Grade 別臨床・病理所見

\begin{tabular}{|c|c|c|c|c|c|c|c|}
\hline Grade & No. & TNM (stage) & $\mathrm{N}$. & $\mathrm{V}$. & 局所再発 & 転 移 & 予後 \\
\hline \multirow[t]{4}{*}{ I } & 4 & $\mathrm{~T} 4 \mathrm{bN} 1 \mathrm{M} 0$ (IV) & / & $\zeta$ & & 4 年 9 か月（肺，腰椎） & 死 \\
\hline & 10 & T 3 a N $0 \mathrm{M} 0$ (II) & - & - & & & 生 \\
\hline & 12 & $\mathrm{~T} 2$ a $\mathrm{N} 0 \mathrm{M} 0$ (I) & - & - & & & 生 \\
\hline & 19 & T 3 b N 0 M 0 (III) & + & - & & & 生 \\
\hline \multirow[t]{10}{*}{ II } & 1 & $\mathrm{~T} 4 \mathrm{bN} 0 \mathrm{M} 0$ (IV) & / & / & 1 年 2 か月 & 2 年 4 か月（脳） & 死 \\
\hline & 3 & $\mathrm{~T} 3$ a N $1 \mathrm{M} 0$ (III) & + & + & & 初診時（リンパ節） & 生 \\
\hline & 5 & $\mathrm{~T} 2 \mathrm{bN} 0 \mathrm{M} 0$ (II) & - & - & & & 生 \\
\hline & 6 & T 4 b N $0 \mathrm{MO}$ (IV) & - & - & & & 生 \\
\hline & 8 & T 4 b N $0 \mathrm{M} 0$ & - & - & 1 年 7 か月 & & 生 \\
\hline & 11 & T 3 b N 0 M 0 (II $)$ & - & - & & & 生 \\
\hline & 13 & T 4 b N $0 \mathrm{M} 1$ (IV) & - & - & & 初診時（肺） & 死 \\
\hline & 15 & T 3 b N 0 M 0 ( II $)$ & + & - & & & 生 \\
\hline & 16 & $\mathrm{~T} 2$ a N $0 \mathrm{M} 0$ (I) & - & - & & & 生 \\
\hline & 18 & $\mathrm{~T} 2 \mathrm{~b} \mathrm{~N} 0 \mathrm{M} 0$ (II) & - & - & & & 生 \\
\hline \multirow[t]{5}{*}{ III } & 2 & $\mathrm{~T} 4 \mathrm{bN} 3 \mathrm{M} 0$ (IV) & $\zeta$ & Y & 1 年 6 か月 & 1 年 6 か月（リンパ節） & 死 \\
\hline & 7 & T 4 b N 0 M 0 (IV) & - & + & 10か月 & 1 年 7 か月（全身骨） & 死 \\
\hline & 9 & T 4 b N 3 M 0 (IV) & / & / & & & 死 \\
\hline & 14 & T 2 b N 0 M 0 (II) & - & - & 3 か月 & & 死 \\
\hline & 17 & $\mathrm{~T} 2$ a N $1 \mathrm{M} 0$ (III) & + & + & 9 か月 & 1 年 5 か月（リンパ節） & 生 \\
\hline
\end{tabular}




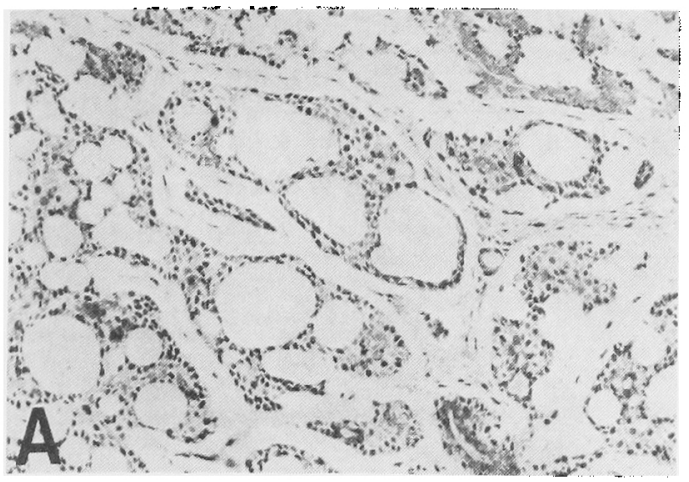

写真 $2 \mathbf{A}$ 抗 $c-m y c$ 蛋白抗体に上る染色所見 多くの瘇瘍勫胞の核に陽性所見を示す $(\times 200)$.

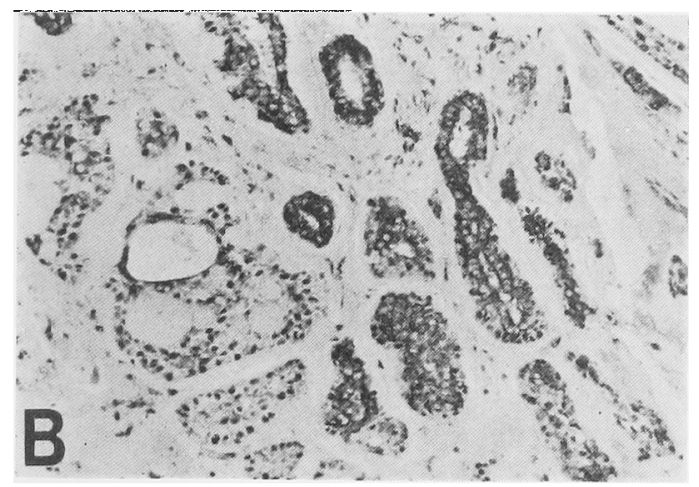

写真 2BAと同じ尰瘍の別の部分

属湟細胞の核飞陽性所見を示す胞单と，細胞質に 陽性所見を示す胞巣がある。主た，核と紐胞質両力 の陽珄像の混在しているるのも認められる $(\times 200)$.

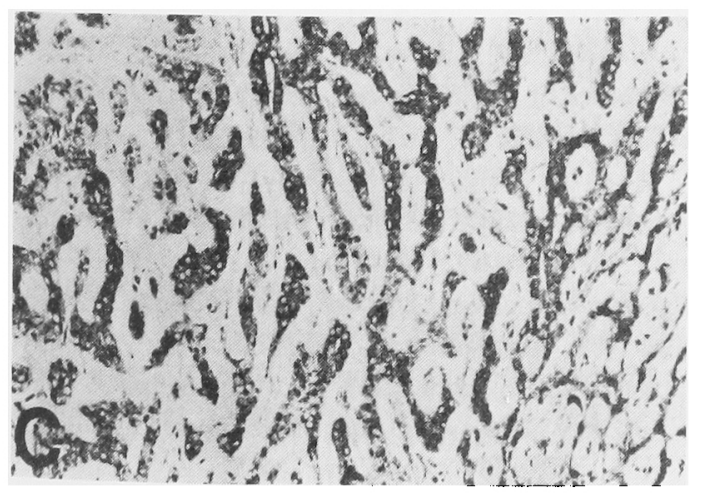

写真 2CA, B 同一茞瘍の別の部分

陽性像の多くは腫窥稩胞の核上りる細胞質に認める $(\times 200)$.

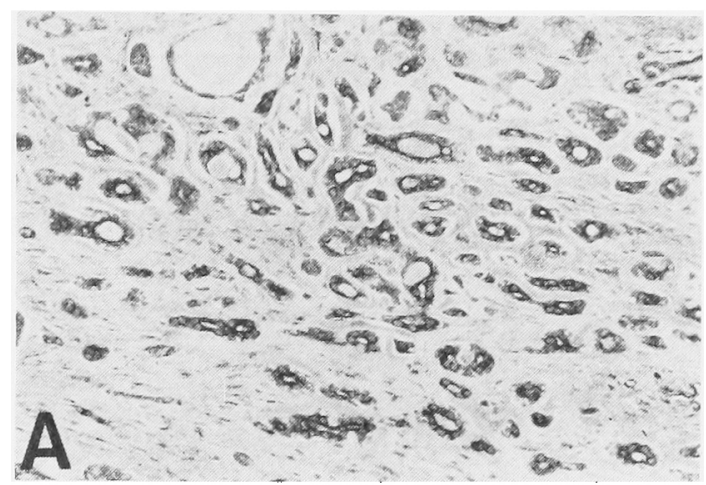

写真 3A 抗 $\operatorname{ras} p 21$ 蛋白の染色所見

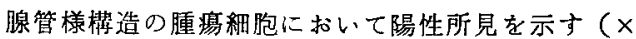
200).

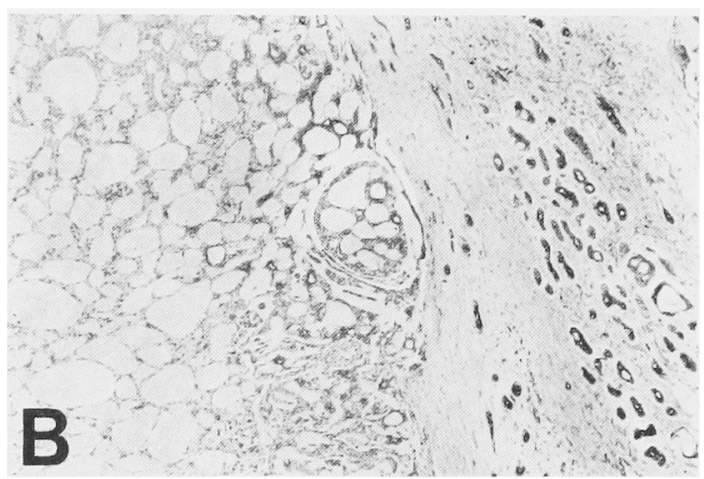

写真 $3 \mathbf{B}$ 大きな胞巣よりも胞巣を形成している部 分でより強い陽性像を示す $(\times 40)$.

侧 (42.1\%) で, 初診時の年龄は 29 歳から93歳にわた り，平均は60.1歳であった。発生部位では口蓋 7 例，口 底 5 例，顎下腺 4 例，頓粘膜 2 例，舌 1 例であり，多く が小唾液腺原発であった。臨床病期分類は， stage I 2 例, stage II 4 例, stage II 5 例, stage IV 8 例であった。

また，これら19例に対する治療法としては，外科療法 单独 8 例, 外科療法と化学療法扣よび放射楾療法の3 者 併用療法 5 例, 放射線療法之外科療法の併用 2 例, 化学 潦法之放射線澄法の併用 1 例, 化学療法単独 1 例, 高龄 につき治療を行わなかったもの1例であった。予後に関 乙て腫瘍死例は 7 例で, T 2 b N OMOの stage II 症 例が 1 例, T 4 b N OMO 2 例, T 4 b N OMI 11 例, T 4 b N I M 01 例, T 4 b N 3 M O 2 例と stage Vの症例が 6 例であった。 なお，予後と治療法との間に はあきらかな相関は認められなかった（表了）。

\section{2. 組織学的所見}

Szanto ら ${ }^{2)}$ の分類により, grade I 4 例, grade II 10 例, grade III 5 例であった。局所再発は 6 例 $(31.6 \%)$ 
表 5 各種癌遣伝子産物の発現率一免疫組織化学的検討一

\begin{tabular}{l|c|c|c|c}
\hline & $c-m y c$ & $\operatorname{ras} P 21$ & $c$-erbB & EGFR \\
\hline Grade I & $3 / 4(75 \%)$ & $4 / 4(100 \%)$ & $3 / 4(75 \%)$ & $0 / 4(0 \%)$ \\
Grade II & $9 / 10(90 \%)$ & $3 / 10(30 \%)$ & $8 / 10(80 \%)$ & $0 / 10(0 \%)$ \\
Grade II & $4 / 5(80 \%)$ & $1 / 5(20 \%)$ & $0 / 5(0 \%)$ & $0 / 5(0 \%)$ \\
\hline
\end{tabular}

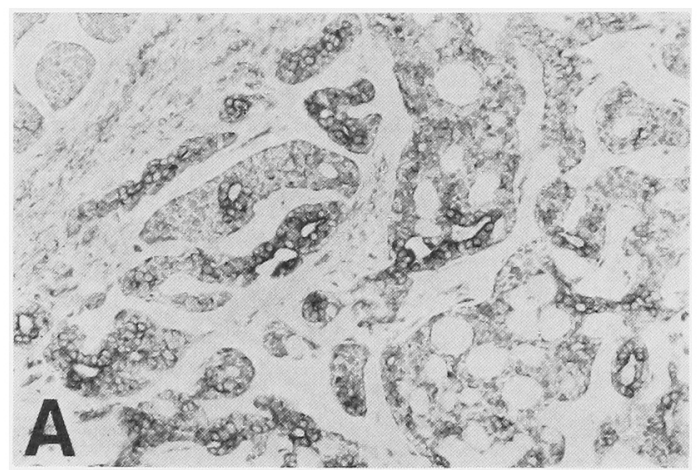

写真 $4 \mathbf{A}$ 抗 $c-e r b B_{2}$ 蛋白の染色所見 腫湯細胞の紹胞質飞陽性所見を認める $(\times 200)$.

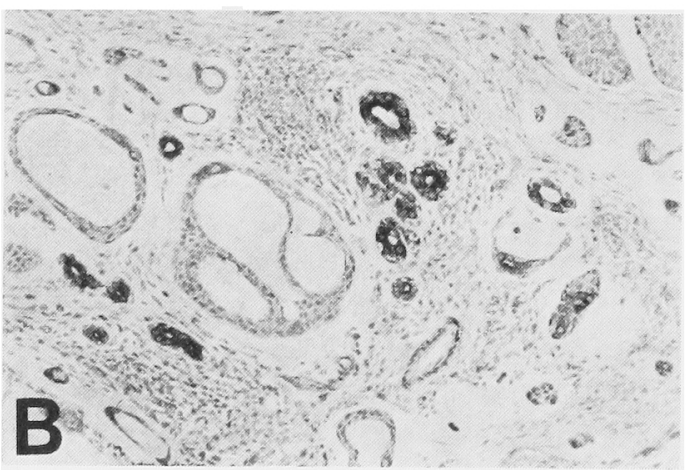

写真 4B 腺管槉構造を示す胞巣にて強い陽性像を 示す $(x 200)$.

に执いて認邓，すへてて 2 年以内に発見されていた。枟移 は初訩時に認めていたもの 2 例，治療後に熟めたもの 5 例の計 7 例で，発見までの期間は 1 年 5 か力から 4 年 9 か月であった，また grade と予後との関係炕批いては， 䦄瘍死例 7 例中 grade I は 1 例, grade II 2 例, grade IIは 4 例であった，死亡むでの期間においても grade I の症例では 5 年 7 か月で㔖ったのに対し，grade III の症 例では， 2 年 5 か月， 2 年 9 か月， 2 年 7 か月， 3 年 2 か月でと比較的短期間であった．また，組織学的検索が 十分火行えた症例で脈管扣よび神経への侵摬を認好たる のは grade I 1 例, grade II 3 例, grade III 2 例の計

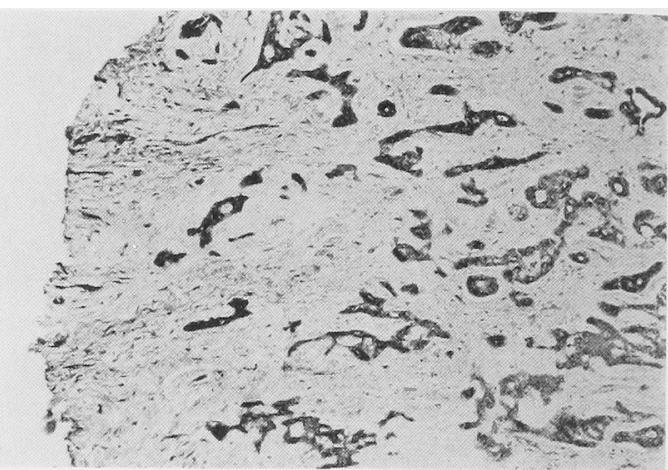

写真 5 腫湯辺㟤部での抗 $c-e r b B_{2}$ 蛋白の染色所 見

尰晹勫胞は結合組織の中を樹枝状に浸潤している が，その汪とんどで強い陽性所見を示す $(\times 100)$. 抗 $\operatorname{ras} P 21$ 抗体に上る染色です同様の所見であっ た.

6 例であったが，局所再発，遠隔転移との関係について はあきらかにできなかった（表 4).

\section{3. 癌寈伝子産物に関する免疫組織学的所見}

$c-m y c$ 蛋白は grade K関係なく，19例中16例 $(84.2$ \%)に陽性であった，c-myc 蛋白はほとんどの例で核内 に陽性所見を認めたが，同一隀演内に扔いて核に陽性所 見を示す部分と細胞質ともに陽性所見を示す部分の混在 するものるあった（写直 2).

ras p 21 蛋白峙 grade I で 4 例全例 (100\%), grade II で10例中 3 例 $(30 \%)$, grade II で 5 例中 1 例 $(20 \%)$ に陽性所見を認めた。 また $c-e r b B_{2}$ 蛋白は，grade Iで 4 例中 3 例 $(7.5 \%)$, grade II で 10 例中 8 例 $(80 \%)$ K 陽性所見を認めたが grade III では陽性所見を認めなか った（写真 3，4）．EGF-R は全症例とも陽性所見を 認めなかった（表 5)。な扰， $\operatorname{ras} p 21 ， c-e r b B_{2}$ 蛋白と 子細胞質に陽性所見を示し，腫湯辺縁部のコンボウ状や 樹枝状を呈して浸潤する部分もしくは小胞巣形成する部 分で，より強く染色される傎向がみられた（写直5）.

また，これら癌遺伝子産物と臨床所見との関連に拀い $\tau$, ras $p 21, c-e r b B_{2}$ 蛋白， EGF $-\mathrm{R}$ については関連が あきらかにされなかったが $c-m y c$ 蛋白に括いて，核 に拉ける陽性所見の他に局所的に細胞質に陽性所見を示 寸細胞集団分認めら九た症例 5 例中（症例 No. 1，4， 
10，13，14）4例では，その子後が著しく苾い傾向にあ った.

\section{考察}

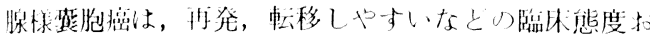

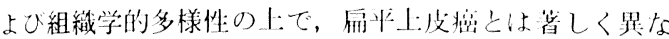
った特徽を有するため，予後に阙しても洏平上皮癌なと とは異なった方法で検討する必要があると考えられる。 そこで，従来の臨床病理学的な检討に加え，癌虺伝子座 物に関して免疫組織学的に㭘討した。

腺様露胞癌において，その予後を左左する臨床的な目 安としては，(1)腫瘍の大きさと転移の有無，(2)神経症状 の有無や硬結程度(局所浸潤程度)などがある ${ }^{19)}$ UICC の唾液腺腫瘍に扣ける TNM 分類 $(1987)^{18}$ に従った今 回の臨床病期分類と尒後との関係では，経過観察期間が 十分とはいえないが，予後不良例 7 例中 stage II の症例 が 1 例, stage IVが 6 例（85.7\%）と子後を反映する結 果が得られた。唾液腺癌の臨床病期分類に阙してはいま まで確立されたものがなかったが，このUICCの分 類 ${ }^{18)}$ は先に述べた臨床的な目安を考虑したものとして意 義があると思われる。特にこの分類に打いて特徵的であ るТ分類での局所浸澗に留しての細分化は，見かけは小 さな腫瘤にみえても強い浸溜を示すことが少なくない唾 液腺腫瘍の評価としては意義があると思われる。しか し, 矢島ら ${ }^{20)}$ も述べているように, 夹際の分類あたり, 唾液腺の被膜外への進展，浸潤程度を把握することは困 難な場合が多く，大血液腺，小挐液腺などの部位的特性 も考虑した評価も今後必要と思われた。

本腫瘍の組織学的検討については，いくつかの分数が 提示され，それぞれ臨㦿所見，予後との関連が報告され ている. Perzin 5 1 は62例の本腫陽に刘し管状型，篩状 型，充実型に分類し後者になるにしたがい再発率が高 く，予後も不良であると報告し，また Szanto ら ${ }^{2)}$ む, 15年にわたる生存率の柃討に扣いて，充类性胞单の割合 が增すにつれ予後不良であるとしている，自験例に扣い ても充皮性胞策が優位な grade III で局所再発，転移が 多く惉められた。 また grade III の症例 5 例中 4 例が腫 湯死であり, grade I の腫瘍死の症例に比し, その経過 も短かった。これらより gradc III の症例は, gradc I , II , の症例に比べ予後不良であり，より悪珄度の高いこ とが示㖫された。腫陽細胞の神経信襲は本腫榎の大きな 特徵であるが，このことが局所再発，転移，予後に既係 するといら報告 ${ }^{21 ~ 23)}$ や最終的な予後には影響しないと する報告1,24) などさまざまである。自騟例に扰いては， 脈管への侵襲の有無もあわせ検討したが，局所再発，転 移などとの相関はあきらかにできなかった。

癌遺伝子産物による腫㾮組織の检討は，これらの腫瘍 マーカーとしての性格のみでなく, 細胞の癌化や覀性
度，転移性といった腫嫄の性格てのものを予测しらるの ではないかと考克られ，臨東への応用も試みられるよら になってきた。

c-mycはトリに myclocytomatosis を引き起こすレト ロウイルスで最初にみつかった遗伝子である。c-myc 蛋

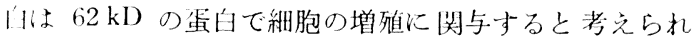
ており，大腸癌，胃癌なとにに扣いて過剩に発現すること が知られている $25 \sim 27)$. 今回の梌索に扣いてい-myc 蛋白 は，その組織型にかかわらす $84.2 \%$ と多くの症例で陽性 所見を認めた。そしてその陽性所見は，腫焬細胞の核に 訫めるものが多かったが，局所的には核に強陽性所見を 示したり，細胞質に陽性所見を示す部分を認めるものも あった。c-myc 蛋白の紐胞内に拈ける局在については, 正常細胞株を用いた研究で核に局在することが示されて いるが ${ }^{28,29)}$ ，細胞分到に際しては，細胞質に分散するこ と，また分裂に閵与しない状態でも少量の $c-m y c$ 蛋白 （5\%以下）は細胞質に見い出されている $5^{4)}$ は，大腸癌に対する $c m y c$ 蛋白の検討において， 非腫竘性粘膜では㤥に陽性を示すものが多く，大腸癌で は練胞質に陽珄を示すことが多いとし，固定条件の関与 もあるが，非腫瘍性粘膜と大腸癌では核に対するc-myc 楅白の状態に差異があるとしており，草深ら ${ }^{31}$ も唾液腺 腫場での $c-m y c ， N-m y c$ 蛋白の検討に打いて同様の報告 をしている。われわれの結果からも，核に対するc-myc 蛋白の状態が多様であることが示唆され，さらにこのよ らな同一腫場内に扣いて多様性をもつ症例の予後が悪か ったことは興味深いと思われた。

ras p 21 蛋白は, 細胞内伝達機構に関与していると 考えられており, 光の量的, 質的変化が, 癌化での重要 な役割を果たしていると考えられている，免疫組織化学 㭘討に拈いても種々の報告がなされているが，悪性度， 子後の推定は困難であるとの報告も多い,8,32,33).今回, ras p 21 蛋白は，上り分化していると考えられている grade I の症例の全例で陽性所見を示し，予後との関連

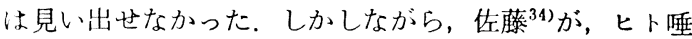
液腺癌培養細胞を用いた実験系に拈いて，ras p 21 蛋白 がその絊胞分化と密接に関連していると報告しているよ 5に，われわれの in vivo に打ける免疫組織化学的検討 でも分化の程度が異なると考光られている各 grade に より発現に差を認め，同様のことが示呶された。

c-erb $B_{2}$ 蛋白は， $\mathrm{EGF}-\mathrm{R}$ と類似の構造をもち，なん らかのレセプターとしての働きをもっていることが示唆

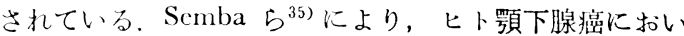
て c-erbB $B_{2}$ 遗后子の増幅があきらかにされて以来注目 され，乳癌においては本遺层子の増幅ならびに遗伝子産 物の発現を認める症例で予後が悪いなど悪性度との相関 があることが報告されている11,36,37)。また，辻ら ${ }^{13)}$ (唾 液腺腫疰の $c-e r b B_{2}$ 蛋白の検討に打いて，本蛋白が，正 常唾液脉では算管細胞に陽性であり細胞分化に関係して 
いること，多形性腺腫の症例において散在性に增殖した 腫瘍細胞や，腺管構造様の腫湯細胞に強陽珄所見を示す ことを報告している．われわれの検討した腺様变胞癌に 扣いて子導管細胞類似の細胞扣よび正常唾液腺導管細胞 に陽性所見を認めた。 また，先に示した ras p 21 蛋白 と同様に浸潤性増殖を示寸細胞強〈陽性反応を示した ことから, ras $p 21$ 蛋白, $c-e r b B_{2}$ 蛋白は分化への関与 とは別に, 尰場細胞の浸潤性增殖にも関与し何らかの働 きをしていると考えられた。

癌遣伝子産物関しては, その生理機能の研究のみな らず，畽瘍診断への応用が期待されているが，活性化さ れた癌遺伝子産物を区別，認識する抗体はなく，量的な 差としてのみとらえらるといらのが現状である。しか し, これらは癌の発生, 增殖, 進展といった癌そのすの の性格に直結することだけに今後，より多面的に研究を 進める必要があると思われた。

\section{結語}

腺様霍胞癌症例19例に対し，臨床扰よび組織学的検討 とともに癌遗伝子産物に対する免疫組織学的検討を行っ た. 臨床的には，病期分類 (UICC, 1987) でのstage I 2 例, stage II 4 例, stage III 5 例, stageIV 8 例であり, 予後不良例は stageIV の高度進行例がほとんどであっ た. 組織学的には grade $\mathbb{I}$ の充実性胞栄が㑑位なもの が予後不良であり，悪性度が高いと思われた，神経，脈 管への浸潤と, 局所再発, 遠隔転移の関係についてはあ きらかにできなかった，癌遺伝子産物の免疫組織学的検 討飞拈いては，c-myc 蛋白は組織学的 grade 飞関係な く $84.2 \%$ に陽性所見を認めたが，同一腫激内で多様な染 色所見を示寸症例で予後不良であった。 $r a s p 21$ 蛋白, $c-e r b \mathrm{~B}_{2}$ 蛋白は分化度が高い之考えられている grade I， II の症例で高率に陽性所見を認め, 細胞分化に関連して いると考えられた。 また，散在性に增殖した腫場細胞 や，腺管構造様の腫演細胞に強く陽性を認め，浸泪性增 殖に関与している可能性が示焧された。

本論文の一部は，败20回日本口腔外科兮会中国・四国 地方会（平成 3 年 4 月 20 日，米子市）に㧤いて発表し た.

\section{引用 文 献}

1) Perzin, K.H., Gullane, P., et al.. Adenoid cystis carcinoma arising in salivary glands: A correlation of histologic features and clinical course. Cancer 42: 265-282 1978.

2) Szanto, P.A., Luna, M.A, et al.: Histologic grading of adenoid cystic carcinoma of the salivary glands. Cancer 54: 1062-1069 1984.
3) Matsuba, H.M., Spector, G.J., et al.: Adenoid cystic salivary gland carcinoma: A histopathologic review of treatment failure patterns. Cancer 57: 519-524 1986.

4) Williams, A.R.W., Piris, J., et al.: Immunohistochemical demonstration of altered intracellular localization of the $c-m y c$ oncogenc product in human colorectal neoplasms. J Pathol 160: 287-293 1990.

5) Kinouchi, T., Saiki, S., et al.: Correlation of c-myc Expression with Nuclear Pleomorphism in Human Renal C'ell Carcinoma. Cancer Res 49: 3627-3630 1989.

6) Matsumura, T., Doki, K., et al.: Alteration and enhanced Expression of the c-myc Oncogene in human Colorectal carcinomas. Pathol Res Pract 186: 205-211 1990.

7) Persson, H. and Leder, P.: Nuclear Localiza tion and DNA Binding Properties of a Protein Expressed by Human $c-m y c$ Oncogene. Science 225: 718-721 1984.

8) Czerniak, B., Chen, R., et al.: Expression of protein in relation to regional spread of human Breast carcinomas. Cancer 63: 200820131989.

9) Tahara, E., Yasui, W'., et al.: Ha-ras oncogene product in human gastric carcinoma: Correlation with invasiveness, metastasis or prognosis. Jpn J Cancer Res (Gann) 77: 517-522 1986.

10）東雅之, 川又均, 他：七ト口腔扁平上皮独 に扣ける RAS 癌遗伝子産物 P 21 の発現と その病態・予後との関速性. 日口外誌 33 : 1281-1286 1987.

11) MacCann, A., Dervan, P.A., et al.: C-erbB-2 oncoprotein expression in primary human tumors. Cancer 65: 88-92 1990.

12) Riviere, A., Wilckens, C., et al.. Expression of $c-e r b \quad B 2$ and $c-m y c$ in squamous cell carcinomas of the head and neck and the lower female genital tract. J Oral Pathol Med 19: 408-413 1990.

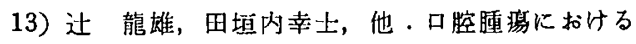
$c-c r b \quad B-2$ 选伝子産物関速抗原の発現。日口外 誌 37: 944-947 1991.

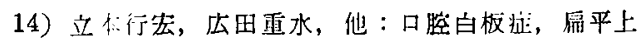
皮癌に打ける EGF 受容体の免疫組織学的検 討. 日只外誌 36: 1438-1444 1990.

15) Yasui, W., Hata, J., et al.: Interaction between epidermal growth factor and its receptor in progression of human gastric carcinoma. Int J Cancer 41: 211-217 1988.

16) Yasui, W., Sumiyosi, H., et al.: Expression of epidermal growth factor receptor in human gastric and colonic carcinomas. Cancer 
Res 48: 137-141 1988.

17) 古江美保, 岡本哲治, 他 : 口陵領域琹性腫演組 織に扣ける上皮成長因子受容体（Epidermal growth factor receptor) の発現。日口外誌 37 : 937-943 1991.

18) Hermaneck, P. and Sobin, L.H.: TMN classification of malignant tumor. 4th Ed UICC Geneva 30-32 1987.

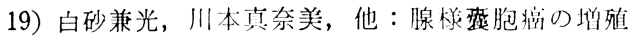
梯式. 日外誌 36：2538-2543 1990 .

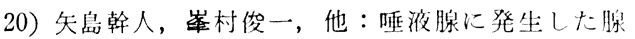

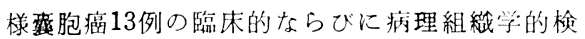
討。 日口外誌 34: 1716-1722 1988.

21）野口高昭, 関谷透, 他: 腺様蒛胞瘦一病理組 織像と予後一。日耳鼻 88: 776-783 1985.

22) Spiro, R.H., Huvos, A.G., et al.: Adenoid cystic carcinoma of salivary origin. A clinicopathologic study of 242 cases. Amer J Surg 128: 512-520 1974.

23) Blanck, C., Eneroth, C.M., et al.: Adenoid cystic carcinoma of the parotid gland. Acta Radiol 6: 177-196 1967.

24) Eby, L.S., Johnson, D.S., et al.: Adenoid cystic carcinoma of the head and neck. Cancer 29: 1160-1168 1972.

25) Stewart, J., Evan, G.I., et al.: Detection of the $c-m y c$ oncogene product in colonic polyps and carcinomas. Br J Cancer 53: 1-6 1986.

26) Slamon, D.J., deKernion, J. B., et al.: Expression of cellular oncogenes in human malignancies. Science 224: 256-262 1984.

27) Ciclitira, P.J., Macartney, J.C., et al.: Expression of $c-m y c$ in non-malignant and premalignant gastrointestinal disorders. J Pathol 151: 293-296 1987.

28) Eisenmann, R.N., Takchibana, C.Y., et al.:
$V-m y c$ and $c-m y c$ encoded proteins are associated with the nuclear matrix. Mol Cell Biol 5: 114-126 1985.

29) Beimling, P., Benter, T., et al.: Isolation and characterisation of the human cellular myc gene product. Biochemistry 24: 6349-6355 1985.

30) Widqvist, R., Saksela, K., et al.: The myc proteins are not associated with chromatinin mitotic cclls. EMBO J 3: 2947-2950 1984.

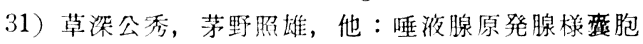
癌に扣ける瘦遗有子産物の㭘索。（抄）幽科基 礎 32 (補冊) 1571990 .

32) Radsevich, J.A., Gould, V.E., et al.. Immunohistochemical analysis of normal and mutated ras oncogene $\mathrm{p} 21$ expression in human pulmonary and pleural neoplasms. Virchows Archiv (Cell Pathol) 56: 377-383 1989.

33) Tujii, T., Sasaki, K.,et al.: The immunohistochemical detection of ras $p 21$ and its corrclation with differentiation in oral cancers. J Tumor Marker Oncol 4: 415-420 1989.

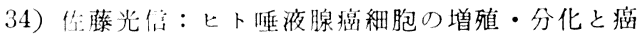
澡伝子。日口科誌 36: 957-981 1985.

35) Semba, K., Kamata, N., et al.: A v-erb Brelated protooncogene, $C$-erb $B-2$, is distinct from the $C$-erb $B-1 /$ epidermal growth factor receptor gene and is amplified in a human salivary gland adenocarcinoma. Proc Natl Acad Sci USA 82: 6497-6501 1985.

36) Barnes, D.M., Larnmie, R.R., et al.: An immunohistochemical evaluation of $c-e r b \quad B-2$ cxpression in human breast carcinoma. $\mathrm{Br} \mathrm{J}$ Cancer 58: 448-452 1988.

37) 豊島久真男 : $C-e r b B-2$ と汃九。㽷と化学療法 17: 309-314 1990. 